\title{
THE ROLE OF WEBSITES AND INTERNET IN ENGLISH TEACHING
}

\author{
Ainur Keldibay ${ }^{1}$, Roza Zhussupova ${ }^{2}$ \\ ${ }^{1}$ Master degree, student of Kyzylorda Korkyt ata university, Kazakhstan \\ ${ }^{2}$ Ass.Pr., C.Ped.Sc., L. N.Gumilyov Eurasian National University, Nur-Sultan, Kazakhstan \\ ${ }^{1}$ ORCID ID: 0000-0001-9724-7429 \\ ${ }^{2}$ ORCID ID: 0000-0003-1850-2052
}

\begin{abstract}
The article is dedicated to using educational Internet resources for teaching English online. This article examined the concepts and essence of educational Internet resources, what criteria teachers should follow when choosing Internet resources, what features of using a foreign language with the help of Internet resources should be considered. The article focuses on the use of internet resources to English language teaching. The information technology has played an important role in English language teaching and it has offered a better tool to explore the new teaching method. The purpose of the article is the use of information technology in increasing the effectiveness of teaching English, developing students' creative abilities at English lessons. There given various available online tools in the Internet for the students and recommend the modern tools for English teachers.
\end{abstract}

\section{INTRODUCTION}

One of the most revolutionary achievements in recent decades, which significantly influenced the educational process around the world, was the creation of a worldwide computer network called the Internet, which literally means "international network".

The Internet is the most useful technology of our time, which helps us not only in everyday life, but also in professional life. For educational purposes, it is widely used to collect information and conduct research or knowledge enhancement in various subjects.

The importance of the Internet in education for learners means that it makes it easier to learn things and re-learn learning, teaching in an educational setting. People use it according to their needs and interests.

As an information system, the Internet offers its users a variety of information and resources. The basic set of services may include:

- e-mail (e-mail);

- teleconferences (usenet);

- video conferencing;

- the ability to publish your own information, create your own home page (homepage) and place it on a Web server;

- access to information resources:

- reference directories (Yahoo !, InfoSeek / UltraSmart, LookSmart, Galaxy);

- search engines (Alta Vista, HotBob, Open Text, WebCrawler, Excite);

- conversation on the network (Chat).

These resources can be actively used in the lesson.

The most common forms of telecommunications (i.e. communication via Internet technologies) are e-mail, chat, forum, ICQ, video, web conferencing, etc., which can be used to master writing and writing. For example, today, with the help of the Internet, one can enter into written communication in on-line mode, creating an authentic situation of dialogical communication in writing. In addition, the Internet makes it possible to implement a communicative approach to teaching, written types of speech activity. Due to the fact that messages on the Internet become, 
potentially available to all users, this increases the responsibility in the knowledge of the language (for example, Chat, Instagram, WhatsApp, Skype).

The involvement of students in the global information flow is both big pros and cons. Similar trends are observed in almost all research related to the problems of Internet education.

M.G. Vasilieva notes that the availability of Internet communications has led to the lack of high-quality analytical activities, students who use the first links in the search engines download ready-made abstracts and term papers. However, on the other hand, the Internet contains many useful resources, the use of which can expand knowledge of disciplines [Vasilyeva, 2014].

As noted by P.V. Sysoev and M.N. Evstigneev, "on the modern stage of training, there is an acute the need to develop new educational online materials, aimed at integrated formation and development:

- aspects of foreign language communicative competence in everything the diversity of its components (linguistic, grammatical, sociocultural, compensatory, educational and cognitive);

- communicative and cognitive skills to search and selection, generalization, classification, analysis and synthesis information received;

- communication skills present and discuss results work with Internet resources;

- the ability to use Internet resources for education and self-education in order to get acquainted with the cultural and historical heritage of different countries and peoples, and also act as a representative of the native culture, countries, cities [Sysoev \& Evstigneev, 2008].

The Internet provides new opportunities and environment for the development of education, while significantly changing the very nature and basic paradigms of education [Alexandrov, 2012; Arsova, 2021; Diachok et al, 2021; Petrova \& Aleksandrov, 2018; Linde \& Petrova, 2018; Sushchenko, Akhmedova, Stryzhak, 2021; Goletiani et al, 2021].

The Internet provides the following opportunities for educational purposes:

- e-mail - for the exchange of information between students and the teacher;

- mailing lists - for sending general information to the study group and collective discussions;

- file transfer using FTP, which allows organizing training of students and trainees through the FTP server with basic teaching and learning materials and software;

- the use of WWW technologies that provide support for the educational process and training in the field of SIT and the organization of distance education with interactive and cooperative elements;

- access to world areas via the Internet.

The development of computer and Web-technologies inevitably leads to the informatization of all types of educational activities, in particular - the creation of information and educational space. The priority areas of creating an information and educational space are the introduction and use of the didactic capabilities of the Internet, Web technologies (Web services, educational Web resources, network communities) in the educational process of higher education, which will allow organizing the learning process so that students are active, with interest. and passionately worked in the classroom, saw the results of their work and could independently evaluate them.

Student use of Internet resources is changing the role teacher (he becomes a consultant and coordinator) and his type communication with students (virtual communication is added) [E-learning Industry]. Various information sites allow the teacher to constantly learn something new, as well as share it with his students [Goroshko, 2009].

There are various tools available in the Internet. This article recommends the following tools for English language teachers.

Wiki is an online application that allows users to contribute to or edit its content. Meaning "quick" in the Hawaiian language, wiki is a creative and open environment where everyone has a voice. The significance of wiki lies in the fact that there is no assigned "leader" or "head writer". The Top 3 Wiki Sites for Teachers are: 


\section{Wikispaces.com}

Wikispaces is a platform for virtual projects that students work on in teams or alone. Teachers monitor student activity in real time, and this can be done from a computer, tablet or smartphone.

The teacher downloads the lecture preparation materials and makes them available to each student individually or as a whole group. While the charges will be discussed in real time.

Wikidot.com

At its most basic level, this website is free to users. Some of its features include easy to use website templates with unlimited pages, free web hosting and domain name, control over ads, and the chance to earn some money with ads, which can be used for the next class trip.

Pbworks.com

This wiki-like website offers educators a range of options that encourage student-centered learning. Students can build web sites or web pages that can be shared with other students and staff [E-learning Industry].

It should be noted that "the use of the Internet in the classroom should not be an end in itself. In order to correctly determine the place and role of the Internet in teaching a language, first of all, you need to find clear answers to the questions: for whom, for what, when, to what extent it should be used. " [Alsagoff et al, p. 27].

There are five types of Internet resources that can be used as individual work of students. On the Internet, you can complete tasks for writing web quests that can be used for individual or group work in the classroom:

1. Hotlist (list by topic) - is a list of Internet sites (with text material) on the topic under study. It is quite simple to create and can be useful in the learning process. The hotlist does not take time to find the necessary information.

All you need is just to enter a keyword into an Internet search engine and you will get the desired hotlist.

2. Multimedia scrapbook (multimedia draft) - is a kind of collection of multimedia resources. Unlike a hotlist, a scrapbook contains links not only to text sites, but also to photographs, audio files and video clips, graphic information, and animated virtual tours that are very popular today. All scrapbook files can be easily downloaded by students and used as informational and illustrative material in the study of a specific topic.

3. Treasure hunt is a lot like hotlist and scrapbook. It contains links to various sites on the topic under study. The only difference is that each of the links contains questions about the content of the site. With the help of these questions, the teacher guides the students' search activities. At the end of the treasure hunt, students may be asked one more general question for a holistic understanding of the topic (factual material). The detailed answer to it will include answers to the previous more detailed questions for each of the sites.

4.Subject sample is stands at the next level of difficulty compared to treasure hunt. It also contains links to text and multimedia materials on the Internet (photos, audio and video clips, graphic information). After studying each aspect of the topic, students are asked to answer the questions posed.

However, unlike the treasure hunt, with the help of which the study of factual material takes place, the sample subject is aimed at discussing socially sensitive and debatable topics.

In group work, it will be necessary to break one topic into several aspects. After discussing their aspect in a group, students can present the results of their discussion to the whole class.

Students need not only to familiarize themselves with the material, but also to express and argue their own opinion on the discussed discussion issue.

5. Webquest (Internet project) is the most complex type of online learning resources. A webquest is a scenario for organizing student project activities on any topic using Internet resources. It includes all the components of the four materials listed above and involves a project with all students. One of the scenarios for organizing students' project activities using Internet resources may have the following structure. First, the whole class gets acquainted with the general information on the topic being studied, thereby plunging into the problem of the upcoming project. Students are then 
divided into groups, and each group is assigned one specific aspect of the topic for study and group discussion [Sysoev \& Evstigneev, 2008].

A Webquest is an inquiry-oriented lesson format in which most or all the information that learners work with comes from the web. Webquests are often completed in small groups, but can be done individually. Small groups are usually the preferred method because the students have more interaction with each other, and can jointly evaluate the information they find on a given website. Webquests traditionally include questions that involve some degree of higher level thinking, so having the students working in groups is a good way to generate a level of involvement and topic discussion that they would not encounter when working by themselves [Vasilyeva, 2014].

Krasnova T.I in her article «Use of Webquest technology in self-directed work of students» gives a detailed description and use of it [Podoprigorova, 2003]. She shows that the given technique is nothing more than the problem task with the elements of role playing using Internet information resources.

Some teachers plan whole lessons around the Internet. For example, Dede Teeler [Skinner, 2003 ] in her book «How to use the Internet in ELT» shows a number of such sequences including designing a lesson around students visiting a teenager advice web site or getting students to make their own newspapers and using a web site for that purpose.

She thinks that the teacher could also ask students to look at a number of different newspaper web sites from Britain and the USA to compare which stories are the most important and how those stories are told. The potential is almost literally endless, of great benefit to them especially if and when they wish to continue studying on their own [Krasnova].

There are lots of user-friendly and fun online platforms that can help English learners master their language skills.

\section{Kahoot!}

Kahoot - is a game, learning platform is used as an educational platform at schools and other educational institutions. The Kahoots educational games are a multi-choice quiz that generates users and are accessible through a web browser.

Kahoot can be an introduction to familiarize students, for formative assessment, or as a break from classroom activities. It also includes trivia quiz!

\section{Lyrics Training}

Thanks to the Lyrics Training portal, students can not only improve their pronunciation, but also learn new vocabulary. The resource presents a large number of various functions: students can choose the track they like and just sing in karaoke mode in English, students can play the game "Add the missing word". Teachers can use Lyrics Training as a distance learning tool by sharing their screens live from home, or sending students a link to practice as homework.

It can take music videos from YouTube and asks learners to fill in the blanks while concentrating on the lyrics. It is simple to play it: the performer sings, the students sing along, the creeping line, which prompts them, the text skips one of the words. Having disassembled it by ear, the students need to write in the missing word. Thanks to such a simple solution, they can not only improve their listening skills, develop other language skills, but also increase their vocabulary.

\section{Quizlet}

Quizlet is a free service that makes it easy to memorize any information that can be presented as learning cards. All that is required is to find in the database or create interactive material - teacher's own cards, adding pictures and audio files to them and then performing exercises and playing games in order to remember this material.

In Quizlet, the theacher can send students a link to a module, course, or they can find them themselves by the teacher's name.

The most important type of human activity - educational, it is regarded as a special form social activity of the individual. Learning activity, like any other, is polymotivated, according to the theory of V.V. Davydov there are three stages [Shchetinina, 2012]. The first is characterized by the development of educational activities. It is carried out only by the direct interaction of the teacher with the teacher. At the second stage, educational actions are combined into holistic acts, cognitive 
interest acquires a stable character with an independent concretization of the goal, control and assessment.The third stage is characterized by cognitiveinterest, generalization, function of the motive of activity.

\section{CONCLUSIONS}

To sum up, The Internet allows you to share various files over long distances. Another user of the world wide web can indicate any question that interests him, and get a response from other users [Goroshko \& Samoilenko, 2011].

The use of the Internet expands the range of real communicative situations, increases the motivation of students, and will make it possible to more effectively apply the acquired knowledge, formed skills, speech skills to solve real communication problems. The relevance and practical necessity of using the Internet in the process of teaching a foreign language is obvious. Since, within the framework of the program for the modernization of higher education, we are talking about the introduction of an activity-based approach in teaching and the successful formation of the communicative and informational competence of students.

The Internet offers many educational benefits. Here is some of them:

1. Economical and affordable education

One of the biggest barriers to education is the high cost. The Internet improves the quality of education, which is one of the foundations of the nation's sustainable development. It provides video tutorials (like YouTube tutorials) and web guides that are accessible to everyone and are very cost effective.

2. Interaction of the student with the teacher and peers

The Internet allows students to keep in constant contact with their teachers or other classmates through social media, messaging apps, and chat forums. Parents can communicate as well as communicate with teachers and school management about their child's progress in the school. Interacting with like-minded people on forums can help students explore new ideas and enrich their knowledge.

3. An effective teaching and learning tool

The Internet has become an effective teaching and learning tool. Teachers can use it in their teaching capacity, post their teaching materials (notes and videos) on the website or forum of the educational institution. The learning process becomes interesting and varied using instructional videos and notes. Teachers can teach using animations, PowerPoint slides, and images to grab students' attention.

4. Easy access to quality education

Students can easily access quality study materials such as YouTube tutorial videos for free or pay online for better study materials. Teachers can also use the Internet to offer students additional learning materials and resources, such as interactive lessons, educational quizzes, and study guides. Teachers can record their lectures and their students for revision, which is better than reading from notes.

\section{REFERENCES:}

Abdykhalykova A., Onlaskan Zh., Abdenova Zh. (2017) The use of information technology in increasing the effectiveness of teaching english"//Scientific electronic library "CyberLeninka", Russia

Alexandrov M.O. One approach for the realization of an online poker game - Funpoker. Proceedings of IX International scientific conference "Science and Education", Kemerovo State University, Belovo Institute (branch), March 28-29, 2012, Belovo, Russia. Vol.1., pp. 124-127

Alsagoff L., McKay S.L., Hu G., Renandya W.A. (2012) Principles and Practices for Teaching English as an International Language. - 362 p. - Routledge, New York 
Arsova, D. (2021). Skills and competencies of the new generation of students to work with digital devices // "Innovations in technology and education": proceedings of XIV International scientific conference "Innovations in technology and education", 26 march 2021 г.: Kuzbass State Technical University, Belovo, Russia; 2021. - vol. 3., pp. 59-66 (in BG)

Bulgakova M.V. (2013) Informacionnyie technology v ekonomike // textbook M.V. Bulgakova. Chelyabinsk: Publishing house Chelyab. state University, 106 p. (Classical university education), Chelyabinsk, Russia.

Diachok, N., Chernukha, N., Tokaruk, L., Udovenko, I., Petrova, M. (2020). Practical-oriented concept as a principle of professional education of the future professionals. International Journal of Higher Education, Vol. 9(4), August 2020, pp.272-282, https://doi.org/10.5430/ijhe.v9n4p272

Goletiani, K., Mushkudiani, Z., Gulua, E., Janelidze, N. (2021). Difficulties in managing diversity in Georgian educational organizations. Access to science, business, innovation in digital economy, ACCESS Press, 2(2): 123-137. https://doi.org/10.46656/access.2021.2.2(1)

Goroshko E.I. (2009) Obrazovanie 2.0 - eto budushee ochestvennogo obrazovanya? (Popytka teoricheskoi refleksii) Part 1. // E.I. Goroshko "Educational technologies and society". T. 12. 2009. - No. 2. - P. 455-469

Goroshko E. I., Samoilenko S. A. (2011) Twitter kak razgovor cherez kontekst: ot Ot obrazovanie $2.0 \mathrm{k}$ Obrazovaniu 3.0?//Int. e-mail magazine "Educational technologies and society (Educational technologies and society)". - T. 14, No. 2. - S. 502-530. - ISSN 1436-4522

Krasnova T.I. The use of webquest technologyin self-directed work of students.

Linde, I., Petrova, M. (2018) The challenges of formalization and modeling of Higher Education Institutions in the 21st century. CBU International conference proceedings 2018: Innovations in Science and Education, 21.-23.03.2018, pp.303-308, https://doi.org/10.12955/cbup.v6.1173

Petrova, M., Aleksandrov, M.(2018). Automating the virtual hosts maintenance in a multi-site environment. International Congress on Business and Marketing (ICBM'18), Marmara Eğitim Köyü Maltepe / İstanbul, TÜRKIYYE, Proceedings of the International Congress on Business and Marketing, 2018 Maltepe University, Istanbul, 29.11.2018-01.12.2018, pp.392-404

Podoprigorova L.A. (2003) internet v obuchenii inostrannym yazikam // IYaSh.-2003.-№5

Shchetinina, M. (2012) Kriterii poiska I otbora Internet-resursov dlya ychebnykh selei // Shchetinina / Information and communication technologies in teaching foreign languages: collection of articles. scientific. Art. / Shadr. state ped. in-t. - Shadrinsk: SHGPI.-S

Skinner B.(2003) Computer Conferencing. Does it motivate EFL students? / Skinner, B and Austin, R. // ELT Journal 53(4)

Sushchenko, O., Akhmedova, O., Stryzhak, O. (2021). The use of interactive training technologies in teaching academic disciplines for students of tourism specialities. Access to science, business, innovation in digital economy, ACCESS Press, 2(1): 28-39. https://doi.org/10.46656/access.2021.2.1(3)

Sysoev P.V., Evstigneev M.N. (2008) Ispolzovanie sovremenniykh interner resursov v obuchenyi inostrannomu yazyku I culture // Language and culture. No. 2. P. 363-371

Teeler D. (2008) How to use the Internet in ELT / D. Teeler. - Pearson Education Ltd

Vasilyeva M.G. (2014) Internet resursy v phizkulturnom obrazovanyi // Physical education of Siberia: scientific and methodological journal. - No. 2. - Omsk. - P. 7-11 